\title{
Identification of tiller age categories based on morphogenetic responses of continuously stocked marandu palisade grass fertilised with nitrogen
}

\author{
Identificação de faixas etárias a partir de respostas morfogênicas de capim-marandu manejado sob \\ lotação contínua e fertilizado com nitrogênio
}

\author{
Adenilson José Paiva ${ }^{\mathrm{I}}$ Lilian Elgalise Techio Pereira ${ }^{\mathrm{I}}$ Sila Carneiro da Silva ${ }^{\mathrm{I}^{*}}$ \\ Raphael Antonio Prado Dias ${ }^{I I}$
}

- NOTE -

\section{ABSTRACT}

Nitrogen fertilization augments tiller appearance and death, modifying the age profile of tiller population. Tillers from different age categories present distinct responses to environmental factors and management practices characterized by variation in their morphogenetic responses, which interfere in the dynamics of the herbage accumulation process. In that context rates of leaf appearance and elongation and leaf lifespan were used as indicators to identify tiller age categories of continuously stocked marandu palisade grass managed at $30 \mathrm{~cm}$ and subjected to nitrogen fertilization regimes using cluster analysis. Analysis was based on the average distance method using combined means of the response-variables studied, and the results used to build a dendogram to illustrate the arrangement of the resulting clusters. Three clusters were identified corresponding to the tiller age categories denominated young (tillers with age between 0 and 60 days), mature (between 60 and 120 days) and old (over 120 days). Discrimination of the tiller age categories according to nitrogen fertilization regime followed the same pattern of clustering. The fact demonstrates consistency and indicates the three age categories as reference for detailed studies regarding the ecophysiology of marandu palisade grass.

Key words: morphogenesis, tiller age category, population dynamics.

RESUMO

A adubação nitrogenada atua na aceleração do aparecimento e mortalidade de perfilhos, alterando o perfil etário da população. Perfilhos de idades diferentes possuem capacidades distintas de resposta a fatores de meio e de manejo, caracterizadas por variação em suas respostas morfogênicas, o que interfere sobremaneira no acúmulo de forragem. Nesse sentido, as variáveis taxa de aparecimento e alongamento foliar e duração de vida das folhas foram utilizadas como descritores para identificar as classes de idade de perfilhos em pastos de capim-marandu, mantidos a 30cm por meio de lotação contínua e taxa de lotação variável, utilizando-se o procedimento multivariado de análise de agrupamentos (Cluster analysis). Foi utilizado o método da distância média, segundo as médias conjuntas dos caracteres avaliados e, com base nesses resultados, um dendograma foi construído. O agrupamento segundo as características morfogênicas taxa de aparecimento e alongamento foliar e duração de vida das folhas revelou variações significativas entre três faixas etárias: perfilhos jovens (0 a 60 dias), perfilhos maduros (60 a 120 dias) e perfilhos velhos (com mais de 120 dias). A discriminação das faixas etárias de acordo com a dose de nitrogênio seguiu o mesmo padrão de agrupamento, indicando valores de referência para futuros estudos mais detalhados acerca da ecofisiologia do capim-marandu.

Palavras-chave: morfogênese, faixa etária de perfilhos, dinâmica de população.

Nitrogen interferes with patterns of tiller appearance and death, altering the age profile of tiller population (PAIVA et al., 2011). Experiments have shown that tiller age influences the turnover of leaves on individual tillers (e.g. MONTAGNER et al., 2011; BARBOSA et al., 2012). According to KITAJIMA et al. (1997), as plants mature their photosynthetic efficiency decreases, with potential negative effects on rates of leaf appearance and elongation (CARVALHO et al., 2001). The fact indicates that tiller age may be one of the main factors that determine morphogenetic responses to tropical forage grasses and highlights a strong ontogenetic effect related to tiller demography and patterns of tiller dynamics in the sward (PAIVA et al., 2011). Studies regarding the effect of plant age

'Departamento de Zootecnia, Escola Superior de Agricultura "Luiz de Queiroz" (ESALQ), Universidade de São de Paulo (USP), 13418-260, São Paulo, SP, Brasil. E-mail: siladasilva@usp.br. *Corresponding author.

IIDepartamento de Ciências Exatas, ESALQ, USP, São Paulo, SP, Brasil. 
during the vegetative state on the tissue turnover in tropical forage grasses are scarce and the few existing use arbitrary criteria for defining tiller age categories to be evaluated. Such information is important and may contribute to refine the understanding of processes involving plant growth and development and planning of efficient management strategies. However, in order to carry out studies like that it is necessary to identify tiller age categories whose characteristics present similar responses to management practices imposed. Physiological responses to defoliation and subsequent growth potential are affected by and strongly influence developmental morphology (PARSONS, 1988). On a tiller level, leaf appearance and elongation as well as leaf lifespan are important morphogenetic characteristics which determine sward herbage accumulation and, therefore, could be used as descriptors of plant growth. In that context, use of morphological characters associated with multivariate analysis techniques have been used for determining similarities or differences between groups of interest (e.g. SILVEIRA et al., 2010). Against that background, the objective of this experiment was to identify classes of tiller age with similar morphogenetic characteristics on continuously stocked marandu palisade grass fertilized with nitrogen using the multivariate procedure of cluster analysis. The experiment was carried out at the Escola Superior de Agricultura "Luiz de Queiroz", Universidade de São Paulo, Piracicaba, SP, from January 2007 to April 2008, on a high fertility Eutric Kandiudalf. Average soil chemical characteristics for the $0-20 \mathrm{~cm}$ layer were: $\mathrm{pH}_{\mathrm{CaCl} 2}$ : 5.0; $\mathrm{OM}=41.6 \mathrm{~g} \mathrm{dm}^{-3} ; \mathrm{P}$ (ion exchange resin extraction method) $=62.1 \mathrm{mg} \mathrm{dm}^{-3} ; \mathrm{Ca}=60.7 \mathrm{mmolc}$ $\mathrm{dm}^{-3} ; \mathrm{Mg}=16.0 \mathrm{mmolc} \mathrm{dm}^{-3} ; \mathrm{K}=6.6$ mmolc $\mathrm{dm}^{-3}$;

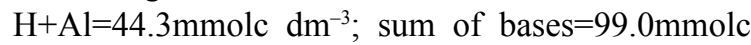
$\mathrm{dm}^{-3}$; cation exchange capacity $=127.5 \mathrm{mmolc} \mathrm{dm}^{-3}$; base saturation $=65.5 \%$. The climate, according to Koppen, is the Cwa mesothermal humid subtropical of dry winter, with average temperatures lower than $18^{\circ} \mathrm{C}$ in the coldest month and higher than $22^{\circ} \mathrm{C}$ during summer. Average daily temperatures varied from 18.0 to $25.8^{\circ} \mathrm{C}$, with minimum and maximum temperatures varying between 10.9 to 20.1 and 25 to $32.5^{\circ} \mathrm{C}$, respectively. Periods of soil water deficit were recorded during March-June and AugustOctober 2007. Swards of marandu palisade grass (Urochloa brizantha Stapf Webster cv. 'Marandu') were maintained at $30 \mathrm{~cm}(27.8$ to $31.0 \mathrm{~cm})$ under continuous stocking with variable stocking rate throughout the experimental period. Monitoring of sward height was performed twice a week using a sward stick and taking 100 readings per experimental unit $\left(1200 \mathrm{~m}^{2}\right.$ paddocks). Treatments corresponded to the application of 150,300 and $450 \mathrm{~kg} \mathrm{ha}^{-1}$ of $\mathrm{N}$ plus the control (no fertilisation) using pure ammonium nitrate, and were allocated to experimental units according to a complete randomised block design, with four replications. Measurements regarding tiller age categories were performed during summer 2008 (February 22 to March 19), time of active plant growth. In order to identify the time of appearance of each tiller, three $30 \mathrm{~cm}$ PVC rings were anchored on the ground in each paddock. At the first measurement (December 14, 2006), all tillers within each ring were counted and tagged with plastic coated wires of a single colour. During all subsequent measurements, all previously tagged tillers still alive were counted and new ones marked with other colour every four weeks. In February 2008 all live tillers within the rings were classified into six age categories according to time of their appearance: less than 30 days of age, 31 and 60 days, 61 to 90 days, 91 to 120 days, 121 to 150 days and more than 150 days. For each six age categories, three tillers were randomly selected within each PVC ring. Identification was made using plastic rings, and tillers were monitored twice a week from February 22 to March 19, 2008. Leaves were identified, their lamina length measured and new leaves counted. The data was used to calculate the rates of leaf appearance (LAR) and elongation (LER) and leaf lifespan (LLS). A multivariate model was used to discriminate tiller age categories based on the three characteristics LAR, LER and LLS - as indicators, isolating the block effect to identify groups according to tiller age. In the sequence, using the means of the studied characteristics, the Euclidean distance between groups was estimated. Based on the distance matrix standardised for zero mean and single variance, a grouping method using the average distance was applied using PROC CLUSTER, and a dendogram built using the PROC TREE of the statistical package SAS $^{\circledR}$ (Statistical Analysis System), version 8.2 for Windows ${ }^{\circledR}$. Validation of the resulting groups was made through multivariate analysis of variance using the $\mathrm{F}$ test to check differences between group means.

Cluster analysis is a multivariate procedure of statistical analysis used to organize objects in groups according to the proximity between them. The objects of the same group are as similar as possible (internal consistency) considering previously defined characteristics and, at the same time, as distinct as possible from the other objects from the remaining groups (external isolation). Leaf appearance (LAR) and elongation (LER) and leaf lifespan (LLS) 
are denominated morphogenetic characteristics. Although genetically determined, they are influenced by environmental variables like temperature, nutrient supply and water availability in the soil. The expression of the three characteristics determines structural characteristics like leaf size, tiller population density and number of live leaves per tiller (LEMAIRE \& CHAPMAN, 1996). Therefore, morphogenetic responses are determinants of variations in sward structure, assuming large importance in studies where the objective is to understand plant responses to variation in environmental conditions and management, and could be used to define similar functional groups of plants (SILVEIRA et al., 2010). Agronomic management practices (e.g. fertilisation, irrigation etc.) that promote increases in herbage production, like nitrogen fertilization, are related to the turnover of tillers in tiller populations, creating gradients of age with distinct potentials of response to environmental factors and management strategies (PAIVA et al., 2011) characterized by reduced rates of leaf appearance as tillers age (Figure 1). KITAJIMA et al. (1997) commented on the strong effect that plant age has over its photosynthetic capacity, structural characteristics and potential productivity, highlighting the importance of knowledge regarding tiller age, variation in tiller age profile of the tiller population according to management practices used and their influence on herbage production. However, despite of their importance, studies of this nature with tropical forage species are scarce. The cluster analysis performed with the marandu palisade grass data resulted in three groups (Figure 1), defined in terms of tiller age categories: tillers under 60 days of age, tillers between 60 and 120 days of age, and tiller over 120 days of age, regardless of the nitrogen fertilization regime used $(\mathrm{P}>0.05)$. Within nitrogen fertilization rates the pattern of morphogenetic responses measured was the same, justifying the grouping. Previous research with mombaça and tanzânia guinea grasses (CARVALHO et al., 2001) and later corroborated by the results of MONTAGNER et al. (2011) and BARBOSA et al. (2012) adopted the same groups defined in this experiment, although defining them based on the average dry weight of individual tillers. CARVALHO et al. (2001) grouped tillers as young (under two months of age), mature (between two and 4 months of age) and old (more

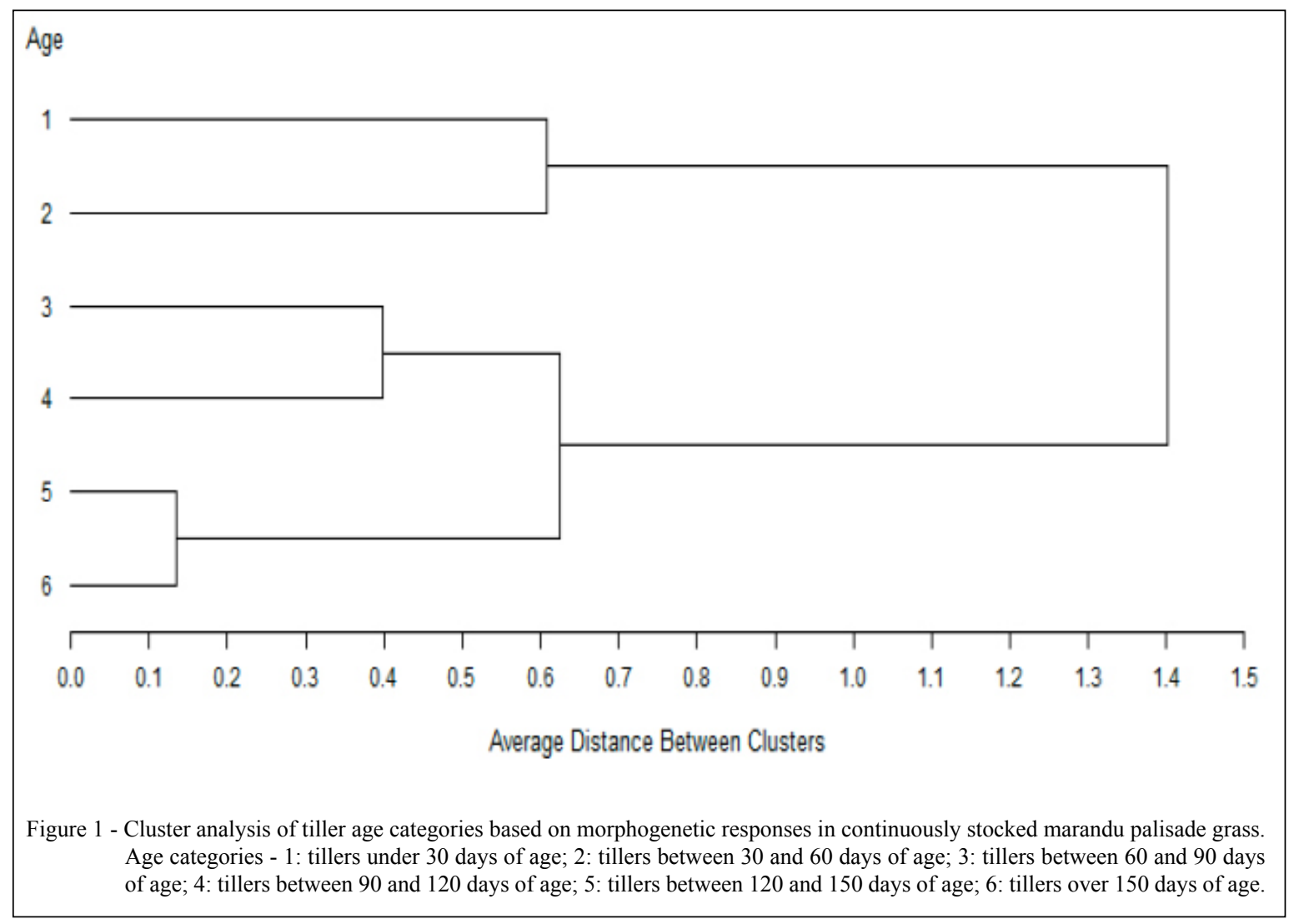

Ciência Rural, v.45, n.5, mai, 2015. 
than 4 months of age). The cluster analysis of this experiment demonstrated that there are differences in plant morphogenetic responses depending on tiller age category, and that those could be well represented by three age categories as follows: young (under 60 days old), mature (between 60 and 120 days old) and old (more than 120 days old) regardless of nitrogen fertilization. Such age categories can be used as reference for detailed studies regarding the ecophysiology of marandu palisade grass.

\section{REFERENCES}

BARBOSA, R.A. et al. Morphogenetic and structural characteristics of guinea grass tillers at different ages under intermittent stocking. Revista Brasileira de Zootecnia, v.41, n.7, p. 1583-1588, 2012. Available from: <http://dx.doi.org/10.1590/ S1516-35982012000700005>. Accessed: Ago. 24, 2012

CARVALHO, D.D. et al. Effect of agging in tillers of Panicum maximum on leaf elongation rate. In: INTERNATIONAL GRASSLAND CONGRESS, 19., 2001, São Pedro, SP. Proceeding... São Pedro: FEALQ, 2001. V.1. p.41-42.

KITAJIMA, K. et al. Decline of photosynthetic capacity with leaf age in relation to leaf longevities for five tropical canopy tree species. American Journal of Botany, v.84, n.5, p.702-708,
1997. Available from: <http://www.amjbot.org/content/84/5/702. full.pdf + html? sid=a107fe8a-55e7-4651-8a2a-fe1978219a46>. Accessed: Ago. 23, 2012.

LEMAIRE, G.; CHAPMAN, D. Tissue flows in grazed plant communities. In: HODGSON J.; ILLIUS A.W. The ecology and management of grazing systems. London: CAB International, (1996). Cap.1, p.3-36.

MONTAGNER, D.B. et al. Morphogenetic and structural characteristics of tillers of guinea grass of different age and grazing severities. Revista Brasileira de Zootecnia, v.40, p.21052110, 2011. Available from: <http://dx.doi.org/10.1590/S151635982011001000006>. Accessed: Ago. 24, 2012.

PAIVA, A.J. et al. Morphogenesis on age categories of tillers in marandu palisadegrass. Scientia Agricola. v.68, n.6, p.626631. Available from: <http://dx.doi.org/10.1590/S010390162011000600003>. Accessed: Ago. 23, 2011.

PARSONS, A.J. The effects of season and management on the growth of grass swards. In: JONES, M.B.; LAZEMBY A. The grass crop: the physiological basis of production. London: Chapman \& Hall, 1988. p.129-177.

SILVEIRA, M.C.T. et al. Morphogenetic and structural comparative characterization of tropical forage grass cultivars under free growth. Scientia Agricola, v.67, n.2, p.136-142, 2010. Available from: $\quad<$ http://dx.doi.org/10.1590/S0103-90162010000200002>. Accessed: Ago. 23, 2012. 